\title{
Harnessing The Potentials of Non-Oil Sectors of The Nigerian Economy to Enhance Sustainable Growth
}

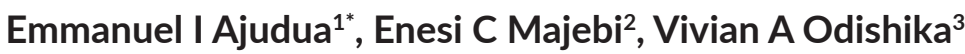

${ }^{1,2,3}$ Faculty of Social Sciences, National Open University of Nigeria

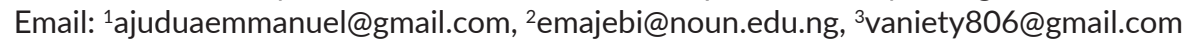

") Corresponding author

\section{JEL Classification:}

$\mathrm{O} 13$

$\mathrm{O} 14$

Q01

Z32

Received: 03 December 2020

Revised: 24 January 2021

Accepted: 26 January 2021

\begin{abstract}
In the face of global oil price instability, which seems to negatively impact the Nigerian economy, this study examined how the Nigerian government and its stakeholders have explored other sectors of her economy, such as agriculture, manufacturing, and tourism, enhancing sustainable growth. In achieving this, the study employed a time series data covering 24 years (1995-2018). The variables used in the study were real gross domestic product (RGDP), tourism share of GDP, agriculture share of GDP, and manufacturing share of GDP. The unit root test using the Augmented Dickey-Fuller test was conducted to test for stationarity among variables employed. The Autoregressive Distributive Lag Bound Test for Co-integration was also employed, while the ECM was also conducted to check for the speed of adjustment. The study findings revealed that, while the Nigerian government and industry stakeholders have made significant investments in the agriculture sector through the development of improved seedlings and farm infrastructure, there is a need for more investment in the manufacturing and tourism sectors of the nation's economy to boost her gross domestic product.
\end{abstract}

\section{Keywords:}

Non-oil sector, agriculture, manufacturing, tourism, sustainable growth.

\section{How to Cite:}

Ajudua, E. I., Majebi, E. C., \& Odishika, V. A. (2021). Harnessing The Potentials of Non-Oil Sectors of The Nigerian Economy to Enhance Sustainable Growth. Signifikan: Jurnal Ilmu Ekonomi, 10(1), 51 - 62. https://doi. org/10.15408/sjie.v9i2.18493. 


\section{Introduction}

The need to harness the non-oil sectors of developing economies' potentials towards enhancing sustainable growth cannot be overemphasized. This is so because a diverse source of income is essential for cushioning out the effect of overdependence on a sector for a nation's economic sustainability. As a developing nation, Nigeria is endowed with abundant natural resources, including the vast expanse of arable land for agriculture, and large crude oil reserves, upon which her economy thrives. Until the end of the 1960s, Nigeria was self-sufficient in terms of food production. The country was a net exporter of agricultural produce, owing to fertile soil types and suitable vegetation and climate for agriculture. However, from the early 1970s, crude oil became a primary foreign exchange earner and revenue source for Nigeria, making it the major contributor to the nation's gross domestic product (GDP).

Today, the Nigerian economy is dominated by crude oil production, and she is rated among the largest producer of the product in the world (Uma et al., 2019). Its monocultural status is further buttressed as reported by that of the N3,915.56 billion total revenue derived in June 2008, N3,133.00 billion was derived from oil (Ameh, 2009). Despite this, Nigeria has a high rate of poverty and was rated as the world's poverty capital in 2019 (Iheonu \& Urama, 2019). This, amongst other reasons, can be attributed to Nigeria's dependence on a resource-based growth strategy driven by the resources generated from her crude oil product sales. However, the variability of crude oil prices in the global market has further contributed to an unstable growth in the Nigerian economy.

As the oil sector remains the mainstay of the Nigerian economy, accounting for about $95 \%$ of the country's revenue generation (Odupitan, 2017), the potentials of the non-oil sectors of Nigeria's economy, including agriculture and manufacturing (Eko et al., 2013), and tourism (Wole, 2018) have not been fully harnessed. This is despite these sectors' potential to contribute to the nation's economy significantly. For example, the agriculture sector's contribution to Nigeria's GDP was $48 \%$ in 1970 , representing the second-largest Nigerian economy sector, after oil (Chukwuma, 2018), and providing employment opportunities for over $70 \%$ of the nation's population. However, in 1980, the agricultural sector's contribution to Nigeria's GDP declined by over 28\% (Chukwuma, 2018). This downward slide in Nigeria's Agriculture sector's contribution to her GDP was also evident in 2015 when the sector contributed $26.2 \%$ of the nation's GDP (Chukwuma, 2018).

The decline in the agricultural sector's contribution to the Nigerian GDP is perhaps responsible for the below-average investment in the manufacturing sector, which can be attributed to the nation's high unemployment rate. For example, the unemployment rate was $11.9 \%$ in 2005 and $21.1 \%$ in 2010 , representing a $10 \%$ rise in unemployment within five years. Currently, Nigeria's unemployment rate stands at $27.1 \%$. This further shows that the agriculture sector's potentials, which can help improve the manufacturing sector and generate employment opportunities for the teeming unemployed Nigerian populace, 
has not been fully harnessed. Similarly, the tourism sector's potential of the nation has not been fully harnessed to contribute to the country's economy. For example, despite the array of Nigeria's natural and human-made tourist attractions across her regions (Awaritefe, 2004; Awaritefe, 2007; Bello \& Bello, 2019), the World Bank Group's 2020 report on international arrivals to Nigeria for the period 2009 to 2015 reveal that the Nigerian travel industry experienced a significant decline in international arrivals from 1 , 500, 000 million tourist arrivals in 2009 to less than 500,000 million arrivals in 2015.

The report suggests a decline in tourist receipts by over $300,000,000$ million dollars between 2008 and 2014, and the loss in tourist arrivals by 1,000,000 within the same period. This decline in both tourist arrivals and receipts can be attributed to the inability of the Nigeria destination managers and other key stakeholders to adopt or develop sustainable strategies that can help harness the sector's potentials amidst crisis events, including political crises and the current COVID-19 pandemic that can make the sector vulnerable (Majebi, 2020). However, despite the Nigerian tourism industry's vulnerability to the crisis, this key non-oil sector of the country's economy remains a viable industry for the sustainable growth of the nation. The importance of the Nigerian tourism sector to her economy is evident in the World Travel and Tourism Council's 2020 report (WTTC 2020), which shows that travel and tourism in Nigeria in 2019 accounted for: (a) $4.5 \%$ of the country's total economy; (b) NGN $6,534.4 \mathrm{BN}$ of the nation's GDP; (c) $4.7 \%$ of total employment, i.e., 3,354.4 million jobs across the tourism subsectors; (d) NGN864.9BN in international visitor spending.

These socioeconomic attributes of the Nigerian tourism sector can be improved to complement the revenue from the Nigerian economy's oil sector. This can be achieved when the nation's relevant government and industry stakeholders develop or adopt sustainable measures to help prevent and reduce the impact of the crisis on the country's economy (Majebi, 2020).

Muttaka (2015) examined the Nigerian economic growth trend and her overreliance on crude oil. According to him, the country has wasted lots of opportunities to break away from underdevelopment despite its massive natural and human resources endowment due to its heavy reliance on crude oil resources, regrettably mismanaged. He identified several key drivers for economic prosperity, such as investment, governance, and regional dimensions of economic diversification and human and natural resources. $\mathrm{He}$ maintained that these drivers remain the prerequisite in building an enabling environment for economic sustainability through sustainable economic policies, but this has been lacking. There is no doubt that the seeming lack of sustainable measures towards harnessing the potentials of the non-oil sectors of the economy to complement the volatility in oil revenue is evident in the country's economic crisis.

For example, in 2016, Nigeria's economy slipped into recession due to a fall in global oil market price, from $\$ 112$ to $\$ 50$ per barrel. This resulted in the fall in Nigeria's public finances and caused chronic dollar shortages in the economy. Consequently, the country recorded negative growth. For example, between the last quarter of 2015 to the 
first quarter of 2017, Nigeria's GDP growth rate was $-0.36 \%,-2.06 \%,-2.34 \%$, and $-1.3 \%$, respectively, for the four quarters of 2016 . The figures were $1.3 \%, 0.55 \%, 1.4 \%$, and $2.6 \%$ for the four quarters of 2017 , showing a gradual exit from the recession from the second quarter of 2017 (Ikon, 2019).

Currently, the Nigerian economy again is on a decline due to yet another slump in global oil price, exacerbated by the ravaging effect of the coronavirus (COVID-19) pandemic. The pandemic initially slowed down, and at a point, halted economic activities worldwide for several months. This led to a fall in global oil demand such that the benchmark price in some cases was lower than the cost of production, and countries are recording low prices, and in some cases, hostile oil prices. As a result, the International Monetary Fund (IMF) had to cut its projection for Nigeria's 2020 economic growth to $2 \%$, from $2.5 \%$ as inflation is expected to rise while deteriorating terms of trade and capital outflows will weaken the country's external position (IMF, 2020). The decline in oil price shock was unexpected and has caused significant strain on the Nigerian government's budget and currency.

This continuous predicament related to global oil price volatility has led to a continuous clamor for economic policies and programs required to cushion the effect of oil price instability on the economy's growth through the activation of specific and vibrant non-oil sectors geared toward raising required economic revenue. This becomes necessary due to the rapidly changing dynamics and volatility of the oil market that has continuously distressed the Nigerian economy (Riti et al., 2016) and the embracement of the 21 st century nuclear, solar, geothermal, and other energy sources to meet the world's energy requirements and control environmental degradation.

Accordingly, Ikon (2019) argues that if the structure of Nigeria's economy were balanced in such a way that other sectors of the economy were developed, Nigeria would have managed the economic shock occasioned by the oil price fall to its advantage. Therefore, this article seeks to support this view as it explores the extent to which the Nigerian government and industry stakeholders have explored other viable economic sectors, including agriculture, manufacturing, tourism, and related subsectors, to cushion the effects of oil price instabilities on its economy.

Hence, as Nigeria is confronted with several economic challenges, its economy's diversification becomes a reliable policy to adopt. Economic diversification involves expanding economic activities, including exploring the potentials of an economy to enhance economic performance that can result in sustainable economic growth. The benefits of diversification of an economy are enormous. It allows a nation to utilize her excellent resource base to rebuild her economy maximally, and enjoy the benefits of all the linkages, synergy, economies of scale, national technology, foreign investment, human capital, exploit new opportunities, low operational costs, increased national competitiveness, improved standard of living and confidence of the citizens for a national renaissance (Suberu et al., 2015).

Options for diversifications no doubt abound in agriculture, taxation, mining, 
manufacturing, tourism, entertainment, financial services, and information and communications technology (ICT) (Anyaechie \& Areji, 2015), among others. In furtherance, the diversification of resources into critical sectors with particular emphasis on the manufacturing industries would reduce the exportation of valuable raw materials overseas. These materials could be transformed into domestic products through the employment of local labor, thereby creating jobs for Nigerians and at the same time multiply the benefit to the national economy.

Several studies (e.g., Esu \& Udonwa, 2015; Suberu et al., 2015; Yusuff \& Akinde, 2015; Kemi, 2016; Chukwuma, 2018; Ikon, 2019; Tonuchi \& Onyebuchi, 2019) that examined measures being deployed by destination authorities of volatile economies to enhance the sustainable growth of their economies have employed different models. This includes the ordinary least square model, autoregressive distributed lag model, and error correction model. For example, Esu \& Udonwa (2015) employed the error correction mechanism (ECM) in examining economic growth in Nigeria through diversification covering 31 years (1980 to 2011), and their study findings reveal that there is a significant negative impact on the non-oil sector on the economic growth of the country. This implies that if the non-oil sectors of the Nigerian economy were given the required attention, it would significantly influence the nation's economy.

Suberu et al. (2015) employed a time series data covering 40 years (1960-2010) in their investigation of Nigeria's diversification of her economy towards sustainable growth and economic development, and their findings reveal that, despite the drop in agriculture's contribution to Nigeria's GDP from $64.27 \%$ in 1960 to $40.84 \%$ in 2010 , the sector remains viable in enhancing the sustainable growth, with sustained strategic policies designed to aid improved investment. Similarly, Yusuff \& Akinde (2015) employed a time series of data spanning 18 years (1995 to 2013) in examining the tourism development and economic growth of Nigeria, and their study findings reveal that there are unilateral causality and positive long-run relationship between tourism development and economic growth.

Kemi (2016) employed descriptive and correlation analysis in investigating the diversification of the Nigerian economy through agricultural production, and her study findings revealed that agricultural production contributes $71 \%$ to employment generation, $76 \%$ to the provision of food, $32 \%$ to foreign exchange earnings, $34 \%$ to poverty reduction and $28 \%$ to the provision of raw materials. Kemi's finding reveals that the correlations between employment generation and economic growth, poverty reduction, and economic growth were positive and significant to the Nigerian economy's sustainable growth.

Chukwuma (2018) employed correlation, cointegration, and ordinary least squares regression models in their study on the diversification of Nigeria's economy through agriculture and solid minerals in the face of dwindling economy, and his study findings reveal that concrete mineral production has a significant short and long-run impact on the Nigerian economy. In the same vein, Ikon (2019) employed the Ordinary Least 
Square method of regression in his study the relationship between economic diversification (proxied by money supply, inflation, import, export, credit to the private sector, and commercial bank loans to manufacturing) and industrial growth (proxied by GDP at current introductory price) in his study on economic diversification and industrial growth in Nigeria, using data which covers 17 years (2000-2017), whose study findings reveals that, there is a significant relationship between economic diversification and industrial growth. This implies that economic diversification can improve industrial growth in Nigeria. However, Tonuchi \& Onyebuchi (2019) employed the autoregressive distributed lag (ARDL) model to investigate the economic diversification of Nigeria. Their findings revealed that non-oil export has a significant positive impact on Nigeria's economic growth in both the short and long run.

A common feature of these extant studies is that they sought to establish how the Nigerian economy's non-oil sectors can contribute to the country's sustainable growth, as this study does. However, in the face of dwindling revenue from the Nigerian oil sector, upon which her economy hitherto thrived, this study seeks explicitly to expound on existing literature by analyzing the extent to which vital non-oil subsectors (i.e., agriculture, manufacturing, and tourism) can contribute to the sustainable growth of the Nigerian economy. This is amidst the unpredictability of her oil revenue, owing to the instabilities in global oil prices. Moreover, it does not seem that there is any recent literature investigating the extent to which a developing economy like Nigeria harnesses its non-oil sectors' potentials to boost its dwindling oil revenue. This makes the study novel, as it aims to show if the contributions of the Nigerian economy's non-oil sectors over a specific period (see methodology section) complements the destination's revenue from the volatile global oil markets.

\section{Method}

The study employed a time series data point index model covering 24 years (19952018). This was to help the authors analyze a time-series sequence of the variables employed for the study to understand their contributions to the Nigerian economy. This is congruent with other studies, including Suberu et al. (2015) \& Yusuff \& Akinde (2015) employed a time series model in investigating the diversification of the Nigerian economy towards sustainable growth.

The variables used in the study were real gross domestic product (RGDP), tourism share of GDP, agriculture share of GDP, and manufacturing share of GDP, and data have gotten were sourced from the Central Bank of Nigerian Statistical Bulletin (Various Issues), the National Bureau of Statistics and the World Bank's Development Indicator (WDI). The model adopted for the study was autoregressive distributed lag (ARDL). This model was adopted since the data's preliminary investigation showed that the data are integrated of order zero and one. The model was used to investigate both the short and long-run relationship among the variables. The model is specified as shown below: 


$$
\begin{aligned}
L G D P_{t}=\beta_{0} & +\sum_{i=1}^{n} \beta_{1} \Delta L G D P_{t-1}+\sum_{i=1}^{n} \beta_{2} \Delta L A G R_{t-1}+\sum_{i=1}^{n} \beta_{3} \Delta L M A N_{t-1} \\
& +\sum_{i=1}^{n} \beta_{4} \Delta L T O U_{t-1}+\theta_{1} L G D P_{t-1}+\theta_{2} L A G R_{t-1}+\theta_{3} L M A N_{t-1} \\
& +\theta_{4} \operatorname{LTOU}_{t-1}+\varepsilon_{t}
\end{aligned}
$$

Where AGR is the Agriculture percent share of the GDP, MAN is the manufacturing percent share of GDP, TOU is the Tourism percent share of GDP, $\Delta$ is the difference operator, $L$ represents the logarithm, $\beta_{0}$ is the constant, $\beta_{0} \beta_{4}$ are the coefficients of the short-run relationships, $\theta_{1} \theta_{4}$ are the coefficients of the long-run relationship and $\varepsilon t$ is the random error term.

Before fitting the proposed model to the data, a unit root test was first of all carried out using the Dickey-Fuller Generalised Least Squares (DF-GLS) proposed by Elliot et al. (1996), which is a modified version of the Augmented Dickey-Fuller and has been shown to perform well in a small sample size. This unit root test method was adopted for this study since the dataset falls in the category of a small sample $(\mathrm{n}<30)$.

\section{Results and Discussion}

\section{Unit Root Test}

The result in Table 1 shows that the variables employed were stationary at the point where the absolute value of the Dickey-Fuller Generalized Least Squares (DFGLS) is greater than the critical value at $5 \%$. From the table, tourism, agriculture, and manufacturing are all integrated of order one $(\mathrm{I}(1))$, which means that they are stationary at first difference while RGDP is integrated of order zero (I(0)) (stationary at levels). This result implies that the regression result cannot be spurious since there is no unit root in the data. Noticeably, the mixture of both $\mathrm{I}(0)$ and $\mathrm{I}(1)$ variables would not be possible under the Johansen procedure. This gives a reasonable justification for using the bounds test approach, or ARDL model proposed by Pesaran et al. (2001).

Table 1. Dickey-Fuller Generalized Least Squares (DF-GLS) Unit Root Test Result

\begin{tabular}{cccc}
\hline VARIABLES & DF-GLS & $5 \%$ & ORDER OF INTEGRATION \\
\hline LTOUR & 4.3662 & 1.9572 & $\mathrm{I}(1)$ \\
LAGR & 4.4926 & 1.9572 & $\mathrm{I}(1)$ \\
LMANU & 2.8630 & 1.9572 & $\mathrm{I}(1)$ \\
LRGDP & 2.7932 & 1.9602 & $\mathrm{I}(0)$ \\
\hline
\end{tabular}

Source: Author's computation from EViews 10 


\section{ARDL Bound Test for Cointegration}

From Table 2, the result of the test for long-run relationship (Bounds test) shows that at a 5\% level of significance, the F-statistic value of 4.626 is higher than the upper bound critical value of 3.67 (see Table 2). This implies that the null hypothesis of no cointegration cannot be accepted at the 5\% level of significance, and we, therefore, conclude the existence of a long-run relationship among the variables employed in the study.

Table 2. ARDL Bounds Test

\begin{tabular}{|c|c|c|c|c|}
\hline \multicolumn{2}{|c|}{ F-Bounds Test } & \multirow{3}{*}{ Sig. } & \multicolumn{2}{|c|}{ Null Hypothesis: No levels relationship } \\
\hline \multirow{2}{*}{ Test Statistic } & \multirow{2}{*}{ Value } & & $I(0)$ & $I(1)$ \\
\hline & & & \multicolumn{2}{|c|}{ Asymptotic: $n=1000$} \\
\hline F-statistic & 4.625876 & $10 \%$ & 2.37 & 3.2 \\
\hline \multirow[t]{3}{*}{ K } & 3 & $5 \%$ & 2.79 & 3.67 \\
\hline & & $2.5 \%$ & 3.15 & 4.08 \\
\hline & & $1 \%$ & 3.65 & 4.66 \\
\hline
\end{tabular}

Source: Author's computation from EViews 10

\section{Long Run Estimate}

The long equation was estimated since the F-Bounds test indicated the existence of cointegration among the variables. The result in Table 3 shows that the long-run coefficient of agriculture contribution AGR to the RGDP is 3.200, which implies that a unit change in AGR will lead to a 3.2 units increase in the RGDP in the long run. The high t-value of 12.435 and the P-value of $0.0000<0.05$ (level of significance) show that the relationship between agriculture and real GDP is statistically significant in the long run. Manufacturing and tourism have a positive relationship with RGDP in the long run though not statistically significant $(\mathrm{P}>0.05)$. This result is in line with Chukwuma (2018), whose study revealed that economic diversification through agriculture and other sources have a significant longrun relationship between economic growth and development.

Table 3. ARDL Long Run Form and Equation

\begin{tabular}{ccccc}
\hline Variable & Coefficient & Std. Error & t-Statistic & Prob. \\
\hline LAGR & 3.200202 & 0.257363 & 12.43461 & 0.0000 \\
LMANU & 1.116295 & 0.659151 & 1.693534 & 0.1212 \\
LTOUR & 1.078913 & 0.699991 & 1.541323 & 0.1543 \\
C & 39.34585 & 10.77594 & 3.651269 & 0.0045 \\
\hline
\end{tabular}

Tonuchi \& Onyebuchi (2019) also support the findings that found a long-run relationship between agriculture, manufacturing, and economic growth. In furtherance, Yusuff \& Akinde (2015) revealed a positive long-run relationship between tourism 
and economic growth in Nigeria. These findings show that agriculture, tourism, and manufacturing play a vital role in Nigeria's growth and development.

$$
\mathrm{EC}=\mathrm{LRGDP}-\left(3.2002 * \text { LAGR }+1.1163^{*}\right. \text { LMANU + 1.0789*LTOUR + 39.3459) }
$$

Table 4. ARDL Short Run Coefficients and Error Correction Mechanism

\begin{tabular}{lclcc}
\hline \multicolumn{1}{c}{ Variable } & Coefficient & Std. Error & t-Statistic & Prob. \\
\hline D(LRGDP(-1)) & 0.371953 & 0.103713 & 3.586361 & 0.0050 \\
D(LAGR) & 0.988590 & 0.212593 & 4.650149 & 0.0009 \\
D(LAGR(-1)) & -0.645385 & 0.317152 & -2.034938 & 0.0692 \\
D(LMANU) & 2.603542 & 0.437211 & 5.954886 & 0.0001 \\
D(LMANU(-1)) & 1.018973 & 0.567704 & 1.794902 & 0.1029 \\
D(LTOUR) & -0.053128 & 0.224278 & -0.236885 & 0.8175 \\
D(LTOUR(-1)) & -0.724270 & 0.266563 & -2.717062 & 0.0217 \\
D(CointEq(-1)* & -0.591218 & 0.103897 & -5.690442 & 0.0002 \\
\hline \multicolumn{1}{c}{ R-squared } & 0.908200 & Mean dependent var & 14.44091 \\
\hline Adjusted R-squared & 0.862299 & \multicolumn{2}{c}{ S.D. dependent var } & 9.597205 \\
\hline
\end{tabular}

\section{Short-run Dynamic ARDL Model}

Examining the model's short-run dynamics (see Table 4), the result shows that the collective impact of manufacturing, tourism, and agriculture on RGDP during the period under investigation is $90.8 \%$ (R-Squared 0.9082 ). This implies that about $91 \%$ variation in RGDP is explained by the independent variables employed in the model. The coefficient of AGR is 0.9896, which means that a unit change in the agriculture share on RGDP will cause a positive change of 0.99 units in the real GDP. The p-value of 0.0009 implies that agriculture has a significant relationship with RGDP in the short run. The previous lag value is negative and significant $(b=-0.645$, $\mathrm{P}>0.05)$. Also, manufacturing has a positive significant short-run relationship with real GDP $(b=2.604, P<0.05)$. This indicates that a unit change in manufacturing will cause a positive change 2.604 units in the RGDP. The relationship between tourism and economic growth in the short run is negative and statistically not significant $(b=-0.0531, P>0.05)$, and the relationship at the previous lag is also negative but significant $(b=-0.724, P<0.05)$. This shows that there is gradual progress in tourism in the long run.

Table 5. Residual Diagnostic Test

\begin{tabular}{ccc}
\hline Test & F- statistic [df] (P-value) & Obs*R-squared [df] (P-value) \\
\hline Serial Correlation & $0.9783[2,8](0.4168)$ & $4.3231[2](0.1151)$ \\
Heteroskedasticity & $1.1698[11,10](0.4061)$ & $12.3796[11](0.3358)$ \\
\hline
\end{tabular}


Having estimated both the short and long run relationships among the variables, it imperative to measure the speed of adjustment from the short run to the long run using the ARDL error correction mechanism. ECM measures the adjustment towards the longrun equilibrium. Positive ECM indicates divergence, while negative shows convergence, which is desirable (Nkoro \& Uko, 2016). The ECM value is negative (-0.5912) and statistically significant at a $5 \%$ level of significance $(\mathrm{P}<0.05)$. This implies that the speed of adjustment to long-run equilibrium is $59 \% .59 \%$ of the disequilibrium in the previous period is being adjusted for in the current period.

Table 6. Test for Normality

\begin{tabular}{cc}
\hline Statistics & Value \\
\hline Mean & $-2.59 \mathrm{e}-14$ \\
Median & -0.294280 \\
Maximum & 6.963972 \\
Minimum & 5.206694 \\
Std. Dev. & 2.907818 \\
Skewness & 0.407385 \\
Kurtosis & 2.792306 \\
Jarque-Bera & 0.648072 \\
Probability & 0.723224 \\
\hline
\end{tabular}

\section{Post Estimation Test}

Post estimation test was conducted on the residual (residual diagnostic test) to check for serial correlation, heteroskedasticity, and normality of the error (residual). The null hypothesis is stated as there is no serial correlation in the residual, no heteroskedasticity in the residual, and the error is normally distributed. The result, as presented in Table 5, shows that the probability values are more significant than the test level of significance $(\mathrm{P}>0.05)$ for both serial correlation (using Breusch-Godfrey serial correlation LM test) and heteroskedasticity (using Breusch-Pagan-Godfrey test). The results imply that the null hypothesis is not rejected. This means that there is no presence of serial correlation and heteroskedasticity. The result in Table 6 shows the Jarque-Bera statistic of 0.6481 and the $P$-value of 0.7232 , which gives no evidence to reject the null hypothesis of normality of the residual.

\section{Conclusion}

The study focused on ascertaining the contribution of the non-oil sector to Nigeria's economic growth since Nigeria's economy depends hugely on oil-dependent, thereby neglecting other sources of revenue and putting Nigeria at the risk of Dutch Disease. Findings revealed a positive and significant short and long-run relationship between agriculture and economic growth. Furthermore, manufacturing showed a positive 
and significant relationship with economic growth in the short run but was positively insignificant in the long run. Also, tourism exhibited an insignificant negative relationship in the short run and a positive one in the long run, indicating a gradual growth process in the sector that can impact the economy if harnessed.

Findings from the study showed the importance of these sectors and the urge to improve the outputs from these sectors to aid in economic growth. To achieve this growth, diversification should be embraced with action such that macroeconomic policies geared toward harnessing the tourism sector's potentials should be introduced. Other recommendations include; a review and fortification of existing policies and incentives to support the non-oil sector's growth-secondly, an improvement in the budget allocation to sectors with the value chain to improve their output. Finally, investment incentives and packages, especially in the tourism sector, can be introduced to encourage investments in the economy's non-oil sector.

\section{References}

Ameh, E. (2009). Oil Price slump and imperative of diversifying the Economy. Business Day Online 12 January 2009. Retrieved from http://www.businessonline.com accessed on $16 / 12 / 201$

Anyaehie, M. C., \& Areji, A. C. (2015). Economic Diversification for Sustainable Development in Nigeria. Open Journal of Political Science, 5(2), 87-94.

Awaritefe, O. (2004). Motivation and Other Considerations in Tourist Destination Choice: A Case Study of Nigeria. Tourism Geographies, 6(3), 303-330.

Awaritefe, O. D. (2007). Evaluating Tourism Resource Areas in Nigeria for Development. Tourism Review, 62(2), 37-45.

Bello, Y. O., \& Bello, M. B. (2019). Destination Attributes and Domestic Tourists' Choice of Obudu Mountain Resort Calabar. Ottoman: Journal of Tourism and Management Research, 4(3), 515-533.

Chukwuma, O. M. (2018). Diversification of Nigeria's Economic Through Agriculture and Solid Minerals in the Face of Dwindling Economic. International Journal of Advanced Research and Innovation, 6(3),147-151.

Eko, S. A., Utting, C. A., \& Onun, E. U. (2013). Beyond Oil: Dual-Imperatives for Diversifying the Nigerian Economy. Journal of Management and Strategy, 4(3),81-93.

Elliot, G., Rothenberg, T. J., \& Stock, J. H. (1996). Efficient Tests for an Autoregressive Unit Root. Econometrica, 64(4), 813-836.

Esu, G. E., \& Udonwa, U. (2015). Economic Diversification and Economic Growth: Evidence from Nigeria. Journal of Economics and Sustainable Development, 6(16),56-68.

Iheonu, C., \& Urama, N. E. (2019). Addressing Poverty Challenges in Nigeria. Retrieved from https://www.africaportal.org/publications/addressing-poverty-challenges-nigerial

Ikon, M. A. (2019). Economic Diversification and Industrial Growth in Nigeria. Journal of Research in Business, Economics, and Management, 13(1), 2408-2415. 
International Monetary Fund [IMF]. (2020). IMF Staff Concludes Article IV Consultation to Nigeria, February 17, 2020, Press Release No. 20/53.

Kemi, A. O. (2016). Diversification of Nigeria Economy Through Agricultural Production. IOSR Journal of Economics and Finance, 7(6),104-107.

Majebi, E. (2020). An Investigation of Stakeholders' Strategies for External Crisis Preparedness: Perspectives of Tourism Industry Stakeholder in Jos, Plateau State, Nigeria. Fudma Journal of Sciences, 4(4), 144-154.

Muttaka, M. (2015). The Intrigues of Nigeria’s Diversification Strategy. Retrieved from: http:// www.dailytrust.com.ng/daily/business/43325-the-intrigues-of-nigeria-sdiversification-Strategy.

Nkoro, E., \& Uko, A. K. (2016). Autoregressive Distributed Lag (ARDL) Cointegration Technique: Application and Interpretation. Journal of Statistical and Econometric Methods, 5(4), 63-91.

Odupitan, E. (2017). Effects of Crashing Crude Oil Prices on Oil Producing Countries: Nigeria's Perspective. (Unpublished Thesis). Centria University of Applied Sciences, Finland

Pesaran, M. H., Shin, Y., \& Smith, R. J. (2001). Bounds Testing Approaches to The Analysis of Level Relationships. Journal of Applied Econometrics, 16(3), 289-326.

Riti, J. S., Gubak, H. D., \& Madina, D. A. (2016). Growth of Non-Oil Sectors: A Key to Diversification and Economic Performance in Nigeria. Public Policy and Administration Research, 6(3), 64-75.

Suberu O. J., Ajala O. A., Akande M. O., \& Olure-Bank A. (2015). Diversification of the Nigerian Economy towards a Sustainable Growth and Economic Development. International Journal of Economics, Finance and Management Sciences, 3(2),107-114.

Tonuchi, J. E., \& Onyebuchi, N. A. (2019). Economic diversification in Nigeria: The Role of Agriculture and Manufacturing Sector. International Journal of Electrical and Computer Engineering, 7(3), 916-926.

Uma, K., Obidike, P., Chukwu, C., Kanu, C., Ogbuagu, R., Osunkwo, F., \& Ndubuisi, P. (2019). Revamping the Nigerian Manufacturing Sub-Sector as a Panacea for Economic Progress: Lessons from South Korea. Mediterranean Journal of Social Sciences, 10(4), 111-123.

Wole, O. (2018). Why Nigerian Tourism Sector Lags amid Huge Potential. The Guardian Nigeria Newspaper - Nigeria and World News, 12 September [Online blog]. Retrieved from: <https://guardian.ng/features/why-nigerian-tourism-sector-lags-behindamid-huge-potential/> [Accessed 30 December 2018].

Yusuff, M. A., \& Akinde, M. A. (2015). Tourism Development and Economic Growth Nexus: Nigeria's Experience. European Journal of Hospitality and Tourism Research, 3(4), 1-10. 